\title{
Performance of Bounty Fresh Broiler Chicken Fed Diet Supplemented with Oregano (Plectranthus amboinicus L.) Leaf Meal
}

\author{
Lilibeth Somera Languido, Mark Joker Lamire Marcos, and Oliva Medina Gaffud
}

\begin{abstract}
A total of (120) day old Bounty Fresh colored broiler chickens were carried out in a completely randomized design to evaluate the effect of different levels of oregano leaf meal (OLM) on the growth performance at a dietary levels of $0,3,6$ and $9 \%$ respectively. Results showed significant in terms of cumulative feed consumption, gain weight and feed conversion ratio. Broilers given $6 \%$ of level of oregano (T3) had the heaviest body weight on the seven week of age with a mean 1955.25 grams while the lightest was those broilers without the supplementation of oregano leaf meal (T1) with a mean of 1743.75 grams. The inclusion of OLM as fed diet were the most efficient feed converter and therefore, has the potential to increase rapid growth and improve vitality and livability of colored broiler chicken. Insignificant result was obtained in terms of the percentage rate of growth, dressing percentage with and without giblets and feed conversion ratio as revealed by the analysis of variance. However, in terms of the income over feed and chick costs, Colored broiler chicken fed with $6 \%$ oregano leaf meal had the highest return of Php 88.89 and the lowest return was those broilers without oregano with a return of Php 50.47.The results suggest that OLM at $6 \%$ level can be safely used as feed ingredients to the broilers without any deleterious effect.
\end{abstract}

Index Terms-growth performance, oregano leaf meal, Bounty Fresh Broiler.

\section{INTRODUCTION}

The cost of poultry production in the country and in other developing countries is the main problem of poultry raisers. Feed represents $60 \%$ to $75 \%$ of the total cost of production. The scarcity and prohibitive cost of commercial energy and protein source like maize and sorghum for poultry ration is one of the reasons of the high cost of poultry feeds. To arrest this situation, poultry raisers all over the world, particularly those of the developing countries are forced to think alternative to reduce their expenses in the production.

Broilers are chickens produced specifically for meat production and have grown dramatically over the years. These improvements are largely due to numerous researches and breeding programs which further enhanced feed utilization, growth rate and low levels of activity. Current commercial hybrids with high performance require high energy diets which would enable the maximum expression of their genetic potential [19] in order to achieve this poultry farmers make use of synthetic growth promoters to enhance feed utilization and growth performance of broilers.

Plant products have been used for centuries by humans as food and to treat ailments. Natural medicinal products originating from herbs and spices have also been used as

Published on April 16, 2020 feed additives for farm animals to improve performance of agricultural livestock [7].

Growth promoters are the substances that are added to a nutritionally balanced diet which provoke response towards the exploitation of maximum genetic potential of the broiler, in terms of growth as well as improvement in feed conversion efficiency. The use of growth promoters has been accepted in the broiler industry and they are usually included in the feed in very small quantities. Many antibiotics are used in animal and poultry feeds as growth promoters to improve the health and well-being of animals and as a prophylactic agent for promoting growth.

Oregano (Plectranthus amboinicus) is a species of Origanum, an aromatic herbal product, because of its highly potent chemical nature and it has been used as a functional herbal product, mainly for preserving food quality, for inhibiting microbial proliferation on ready-to-cook poultry meat, and, more recently, as an alternative growth promoter in swine and poultry nutrition . Carvacrol, thymol, $\gamma-$ terpinene, and $\rho$-cymene are the most important components of oregano essential oil involved in the functional properties of oregano ([3], [9] and [17]). Proximate analysis showed that oregano contained also $8.9 \%$ moisture, $13.3 \%$ protein, $4.1 \%$ fat, $19.0 \%$ crude fibre, and $9.1 \%$ ash. This plant is used by farmers for its medicinal use.

Based on several studies conducted and reported, oregano is an alternative feed additive that may have potential to replace subtherapeutic antibiotics in livestock feed [16]. [8] Investigated the influence of oregano products (oil extract or its dried leaf) on broiler performance, concluded also that oregano has the potential to promote broiler performance and reduce bacterial inhabitants of the gastrointestinal tract such as Clostridium perfringens and Escherichia coli. However, prediction of the broiler response to oregano and other herbal supplements is not straightforward; it is highly influenced by herbal variety [17], [4], [11], [14], level of supplementation [2], [6], environmental and sanitary conditions (challenged vs. unchallenged), nutrient composition of the diet [13] and [5], and the possible interaction with other additives such as organic acids [5].

In order to make use of the naturally existing chemicals in the structure of a plant, it is advisable to use such plants in natural forms rather than in processed forms. Hence, there is a need to investigate these indigenous feedstuffs with medicinal properties to find out their potential as a safer alternative to antibiotics and asses if they can affect rapid growth and improve feed efficiencies of colored broiler chicken. This study was conducted to evaluate the growth performance of broiler in terms of body weight, gain in weight, percentage rate of growth, feed consumption, 
feed conversion ratio and efficiency, dressing percentage, carcass quality and sensory characteristics, red blood cells count, and determine the level of oregano ( $P$. amboinicus) leaf meal that would give the best result based on income over feed cost in broilers.

\section{MATERIALS AND METHODOLOGY}

\section{A. Chicks, diets and management}

The experiment was conducted in Student Instructional Unit (SIU) of the Department of Animal Science \& Animal Husbandry, College of Agriculture, Isabela State University, Echague, Isabela. A total of 120 day-old Bounty Fresh colored broiler chicks were randomly allotted into four (4) treatments and replicated thrice with 10 birds per replication. They were vaccinated for Newcastle Disease as a preventive measures. The dietary treatments were as follows: T1 - Control (Formulated feeds without oregano leaf meal, T2 - Formulated feeds with 3\% oregano leaf meal (OLM), T3 - Formulated feeds with $6 \%$ oregano leaf meal (OLM), T4 - Formulated feeds with $9 \%$ oregano leaf meal (OLM).

Table 1. The Composition and calculated nutrient analysis of starter home mixed ration used in the study.

\begin{tabular}{|c|c|c|c|c|}
\hline Ingredients & $\mathbf{T}_{1}$ & $\mathbf{T}_{2}$ & $\mathbf{T}_{3}$ & $\mathbf{T}_{4}$ \\
\hline Oregano leaf meal & - & 3.00 & 6.00 & 9.00 \\
\hline Rice bran & 12.00 & 12.00 & 12.00 & 12.00 \\
\hline Fish meal & 6.00 & 6.00 & 6.00 & 6.20 \\
\hline Soybean meal & 24.30 & 23.08 & 23.20 & 22.40 \\
\hline Corn meal & 53.17 & 50.37 & 49.00 & 45.65 \\
\hline Salt & 0.40 & 0.40 & 0.32 & 0.30 \\
\hline Oil & - & 0.50 & 1.02 & 2.03 \\
\hline Dicaphos & 0.15 & 0.15 & 0.18 & 0.15 \\
\hline Limestone & 0.70 & 0.70 & 0.70 & 0.70 \\
\hline Methionine & 0.80 & 0.80 & 0.10 & 0.10 \\
\hline Min./Vit. Premix & 0.50 & 0.50 & 0.50 & 0.50 \\
\hline Antioxidant & 0.20 & 0.20 & 0.20 & 0.20 \\
\hline Total & 100 & 100 & 100 & 100 \\
\hline \multicolumn{5}{|c|}{ CALCULATED ANALYSIS } \\
\hline Ingredients & $\mathbf{T}_{1}$ & $\mathbf{T}_{2}$ & $\mathbf{T}_{3}$ & $\mathbf{T}_{4}$ \\
\hline Crude Protein & 20.03 & 20.04 & 20.09 & 20.04 \\
\hline $\begin{array}{l}\text { Metabolized } \\
\text { Energy }\end{array}$ & $2,845.00$ & $2,808.78$ & $2,807.04$ & $2,805.26$ \\
\hline Calcium & 0.89 & 0.88 & 0.87 & 0.88 \\
\hline Phosphorous & 0.41 & 0.41 & 0.41 & 0.41 \\
\hline Lysine & 1.17 & 1.15 & 1.13 & 1.11 \\
\hline Methionine & 0.42 & 0.41 & 0.42 & 0.42 \\
\hline
\end{tabular}

A formulated ration was used throughout the study. The ingredients used were corn meal, rice bran, fish meal, salt, vitamins, limestone and oregano leaf meal (Table 1 and 2). Feed and water were provided ad libitum at all times during the experimental period. Oregano leaves was collected from the vicinity of Echague, Isabela. The fresh leaves were air dried until they can be pounded to powder form. This was then mixed with other basal feed ingredients to make a formulated ration based on the nutrition requirements of broilers. The management of the birds was in accordance with the guidelines of raising broilers. The birds were raised in wire floor cages and subdivided into 12 experimental units with a measurement of $1.0 \times 1.25$ meters at each pen. The temperature of the broiler house was $310 \mathrm{C}$ for the first 2 weeks and then gradually decreased to $250 \mathrm{C}$ over the next two weeks and for the remaining time was kept at $250 \mathrm{C}$.
Among the data to be gathered were the body weight, gain in weight, feed consumption, feed conversion ratio and efficiency, percentage rate of growth, dressing percentage and income above feed and chick costs.

Table 2. The Composition and calculated nutrient analysis of finisher home mixed ration used in the study.

\begin{tabular}{|c|c|c|c|c|}
\hline Ingredients & $\mathbf{T}_{1}$ & $\mathbf{T}_{2}$ & $\mathbf{T}_{3}$ & $\mathbf{T}_{4}$ \\
\hline Oregano leaf meal & - & 3.00 & 6.00 & 9.00 \\
\hline Rice bran & 16.00 & 15.00 & 15.00 & 15.00 \\
\hline Fish meal & 5.00 & 5.00 & 6.00 & 6.00 \\
\hline Soybean meal & 21.70 & 20.35 & 19.05 & 18.80 \\
\hline Corn meal & 52.88 & 52.00 & 50.50 & 46.47 \\
\hline Salt & 0.30 & 0.30 & 0.30 & 0.30 \\
\hline Oil & - & 0.50 & 0.90 & 2.10 \\
\hline Dicaphos & 0.18 & 0.20 & 0.20 & 0.18 \\
\hline Limestone & 0.70 & 0.70 & 0.70 & 0.70 \\
\hline Methionine & 0.40 & 0.50 & 0.50 & 0.50 \\
\hline Min./Vit. Premix & 0.50 & 0.50 & 0.50 & 0.50 \\
\hline Antioxidant & 0.20 & 0.20 & 0.20 & 0.20 \\
\hline \multirow[t]{2}{*}{ Total } & 100 & 100 & 100 & 100 \\
\hline & \multicolumn{4}{|c|}{ CALCULATED ANALYSIS } \\
\hline Ingredients & $\mathbf{T}_{1}$ & $\mathbf{T}_{2}$ & $\mathbf{T}_{3}$ & $\mathbf{T}_{4}$ \\
\hline Crude Protein & 18.79 & 18.47 & 18.75 & 18.78 \\
\hline $\begin{array}{l}\text { Metabolized } \\
\text { Energy }\end{array}$ & $2,847.00$ & $2,830.96$ & $2,810.68$ & $2,805.62$ \\
\hline Calcium & 0.81 & 0.81 & 0.87 & 0.88 \\
\hline Phosphorous & 0.39 & 0.39 & 0.42 & 0.41 \\
\hline Lysine & 1.07 & 1.03 & 1.04 & 1.02 \\
\hline Methionine & 0.35 & 0.35 & 0.36 & 0.35 \\
\hline
\end{tabular}

\section{B. Statistical analysis}

Data were subjected to Analysis of Variance of Completely Randomized Design and carried out using the Statistical Tool for Agricultural Research (STAR).

\section{DISCUSSION}

The responses of colored broiler chicken fed diet supplemented with oregano (Plectranthus amboinicus) leaf meal in different growth periods are presented in Table 3. Statistically, insignificant differences among treatments on their initial body weight of the birds with a mean ranging from 180.36 to 188.90 grams. The insignificant result indicates homogeneity or uniformity of the experimental units.

Likewise comparable body weight was noted on the first, fourth, fifth, sixth week of the study. However, on the second week of the study, a highly significant result was obtained. Broilers given $6 \%$ of level of oregano (T3) had the heaviest body weight with a mean 760.86 grams while the lightest was those broilers without the supplementation of oregano leaf meal (T1) with a mean of 642.70 grams. Same trend also on the third week and seventh week of the study that broilers given $6 \%$ level of oregano had obtained the highest result over those on broiler in $\mathrm{T} 1$. 
Table 3. Responses of colored broiler chicken fed diet supplemented with oregano (Plectranthus amboinicus) leaf meal in different growth periods.

\begin{tabular}{cccccc}
\hline \multirow{2}{*}{ Week } & \multicolumn{5}{c}{ Body Weight } \\
\cline { 2 - 5 } & $\mathrm{T}_{1}$ & $\mathrm{~T}_{2}$ & $\mathrm{~T}_{3}$ & $\mathrm{~T}_{4}$ & $\begin{array}{c}\text { C.V. } \\
\%\end{array}$ \\
\hline Initial $^{\mathbf{n s}}$ & 188.56 & 181.26 & 180.36 & 188.90 & 1.44 \\
$1^{\mathbf{n s}}$ & 435.56 & 424.76 & 437.36 & 454.73 & 1.21 \\
$2^{* *}$ & $642.70^{\mathrm{b}}$ & $749.03^{\mathrm{a}}$ & $760.86^{\mathrm{a}}$ & $756.63^{\mathrm{a}}$ & 3.32 \\
$3^{* *}$ & $950.50^{\mathrm{b}}$ & $971.60^{\mathrm{b}}$ & $1068.83^{\mathrm{a}}$ & $951.83^{\mathrm{b}}$ & 0.88 \\
$4^{\mathrm{ns}}$ & 1255.00 & 1260.84 & 1336.03 & 1313.06 & 1.36 \\
$5^{\mathrm{ns}}$ & 1478.70 & 1485.84 & 1561.45 & 1546.56 & 1.79 \\
$6^{\text {ns }}$ & 1665.58 & 1645.79 & 1757.15 & 1659.96 & 1.85 \\
$7^{* *}$ & $1743.75^{\mathrm{c}}$ & $1845.64^{\mathrm{b}}$ & $1955.25^{\mathrm{a}}$ & $1815.16^{\mathrm{b}}$ & 0.27 \\
\hline ns $^{*}$ not significant $(P>0.05)$ & & & \\
$* *$ & Significant at $1 \%$ Level of significance $(P<0.01)$ & &
\end{tabular}

This observation was in contrast with the study of [15] who supplemented broiler diets with dried oregano leaf but had no significant effect on body weight of broiler. In addition, the origin of the dried oregano leaf (Mexican vs. Mediterranean) or the levels of supplementation (2.5, 5.0, 10.0 , or $20.0 \mathrm{~g} / \mathrm{kg}$ of basal diet) had no significant effect on the broiler's body weight. It is interesting to note however, that the numerical advantage of the treated birds of the present study revealed that the body weight was affected by the inclusion of different levels of leaf meal on the first 3 weeks of the study. The numerical advantage of the treated birds clearly shows the potential of the indigenous feed resources as an alternative growth promoter and antibiotic.

Table 4 is the percentage rate of growth of colored broiler chicken. It was observed that on the third week of the study the analysis of variance revealed significant differences among treatments. The result of this study conforms to the findings of [18] who stated that chicken's gradually decrease as the chicken grew older. On the first three weeks of the study the growth rate normally shoot up and gradually decreases as the chicks grows.

Table 4. Percentage Rate of Growth (\%) of the Colored Broiler Chicken Fed Diet Supplemented with Oregano (Plectranthus amboinicus) Leaf Meal

\begin{tabular}{|c|c|c|c|c|c|}
\hline \multirow{2}{*}{ Week } & \multicolumn{4}{|c|}{ Percentage Rate of Growth } & \multirow[b]{2}{*}{$\begin{array}{c}\text { C.V. } \\
\%\end{array}$} \\
\hline & $\mathrm{T}_{1}$ & $\mathrm{~T}_{2}$ & $\mathrm{~T}_{3}$ & $\mathrm{~T}_{4}$ & \\
\hline $1^{\mathrm{ns}}$ & 79.20 & 80.36 & 83.22 & 82.64 & 0.76 \\
\hline $2^{\text {ns }}$ & 34.37 & 44.77 & 44.38 & 43.200 & 9.09 \\
\hline $3 *$ & $38.75^{\mathrm{a}}$ & $25.75 b^{c}$ & $33.61^{\mathrm{ab}}$ & $22.85^{\mathrm{c}}$ & 3.87 \\
\hline $4^{\text {ns }}$ & 27.54 & 25.92 & 22.23 & 31.65 & 4.47 \\
\hline $5^{\text {ns }}$ & 16.18 & 16.31 & 15.48 & 16.34 & 5.17 \\
\hline $6^{\mathrm{ns}}$ & 11.88 & 10.13 & 11.87 & 6.99 & 7.58 \\
\hline $7^{\mathrm{ns}}$ & 10.48 & 17.41 & 3.25 & 20.02 & 24.77 \\
\hline
\end{tabular}

Table 5 shows the weekly and cumulative feed consumption of colored broiler chicken. On the first, second and third week of the study, a significant result was obtained. Colored broilers chicken in T3 was significantly different compared with those colored broiler chicken in T2 and $\mathrm{T} 4$ however, $\mathrm{T} 1, \mathrm{~T} 3$ and $\mathrm{T} 4$ were comparable with each other. This means that the colored broiler chicken in T2 consumed the higher amount of feeds than the colored broiler chicken in T3 but statistically, the same amount with $\mathrm{T} 1$ and $\mathrm{T} 4$ and The least amount of feed consumption was in $\mathrm{T} 3$.
Table 5. Weekly and Cumulative Feed Consumption of the Colored Broiler Chicken Fed Diet Supplemented with Oregano (Plectranthus amboinicus) Leaf Meal

\begin{tabular}{|c|c|c|c|c|c|}
\hline \multirow{2}{*}{ Week } & \multicolumn{4}{|c|}{ FEED CONSUMPTION } & \multirow{2}{*}{ C.V.\% } \\
\hline & $\mathrm{T}_{1}$ & $\mathrm{~T}_{2}$ & $\mathrm{~T}_{3}$ & $\mathrm{~T}_{4}$ & \\
\hline $1 *$ & $177.43^{\mathrm{a}}$ & $167.50^{\mathrm{b}}$ & $183.36^{\mathrm{a}}$ & $164.46^{\mathrm{b}}$ & 1.00 \\
\hline $2 *$ & $542.57^{b}$ & $561.43^{\mathrm{ab}}$ & $575.60^{\mathrm{a}}$ & $557.03^{\mathrm{ab}}$ & 0.50 \\
\hline $3 * *$ & $650.46^{\mathrm{d}}$ & $672.63^{b}$ & $689.66^{\mathrm{a}}$ & $6.59^{\mathrm{c}}$ & 0.17 \\
\hline $4^{\mathrm{ns}}$ & 692.76 & 711.22 & 733.71 & 695.10 & 0.69 \\
\hline $5^{\mathrm{ns}}$ & 831.90 & 855.22 & 861.50 & 818.80 & 1.07 \\
\hline $6^{\mathrm{ns}}$ & 828.79 & 835.55 & 838.06 & 797.66 & 1.86 \\
\hline $7^{* *}$ & $824.90^{\mathrm{b}}$ & $850.85^{\mathrm{a}}$ & $865.37^{\mathrm{a}}$ & $820.17^{b}$ & 0.28 \\
\hline Cumulative* & 4548.83 & 4654.42 & 4747.28 & 4513.01 & 0.49 \\
\hline
\end{tabular}

On the other hand, from fourth week up to the sixth week of the study, a comparable result was obtained, which means that all the colored broiler chicken from the different treatments consumed the same amount of feeds.

In terms of the cumulative feed consumption of the broiler chicken, a significant result $(\mathrm{P}<0.01)$ was observed among the treatments. The significantly lower feed intake could be due to the texture of oregano leaf meal might have imparted unpalatable taste to the feed, which consequently inhibited the birds from consuming adequate quantities which was similarly observed by [12]. The findings of the study agree with the observation that monogastrics cannot fully utilize high crude fibre diets efficiently. The foregoing results of the study clearly demonstrate that bulkiness of the experimental diets such as those in $\mathrm{T} 3, \mathrm{~T} 4$ and $\mathrm{T} 5$ that contributed to the reduction of feed intake and consequently, lower level of nutrients available for the growing birds.

Likewise, the cumulative feed consumption showed insignificant result. All the colored broiler chicken consumed similar amount of feeds. This means that for the whole feeding period, the amount of feed consumed by the colored broiler chicken was not affected by the level or amount of oregano leaf meal. This may be due to the unpalatability of the oregano at higher concentrations which may be associated with the oil component and bitter taste of oregano which may have possibly prevented the chicken to consume feed hence, the birds did not gain much in weight.

This finding was also similar with [16] who observed reluctance in feed consumption of nursery pigs with higher concentration of oregano.

The average gain in weight, feed conversion ratio and efficiency are shown in Table 6. The result revealed significant differences among treatments in terms of the gain in weight of the colored broiler chicken among treatments with mean ranging from 1,555.18 grams to $1,774.88$ grams. The significantly higher weight gained on the different treatments however was attributed mainly on the higher nutrient intake of those birds as revealed on the weekly feed consumed of the experimental treatments. The analysis showed that all the different treatments had statistically the same amount of feeds consumed to produce a kilogram gain in weight with an average ratio of 2.67 to 2.92 grams. A low feed conversion ratio is a good indication of high quality feed. The same trend was observed in terms of feed conversion efficiency. In terms of the feed conversion efficiency, results of the study revealed significant differences among treatments were observed. 
Broilers fed with the inclusion of $6 \%$ oregano leaf meal were the most efficient in converting feeds into meat with an average efficiency mean 37.39 percent. The significantly better feed conversion ratio and feed efficiency clearly demonstrate the potential of the indigenous feed resources as an alternative growth promotant and as a substitute for antibiotic that will increase vitality and livebability of colored broiler chicken.

Table 6. Gain in Weight (g), Feed Conversion Ratio (kg) and Efficiency (\%)of the Colored Broiler Chicken Fed Diet Supplemented with Oregano (Plectranthus amboinicus) Leaf Meal

\begin{tabular}{|c|c|c|c|c|c|}
\hline \multirow[b]{2}{*}{ Parameter } & \multicolumn{4}{|c|}{ Treatment } & \multirow{2}{*}{$\begin{array}{l}\text { C.V } \\
\%\end{array}$} \\
\hline & $\mathrm{T}_{1}$ & $\mathrm{~T}_{2}$ & $\mathrm{~T}_{3}$ & $\mathrm{~T}_{4}$ & \\
\hline Gain & & & & & \\
\hline $\begin{array}{l}\text { Weight } \\
(\mathrm{g})^{* *}\end{array}$ & 1555.187 & 1664.38 & 1774.887 & 1626.26 & 0.36 \\
\hline $\begin{array}{l}\text { FCR } \\
(\mathrm{kg})^{\text {ns }}\end{array}$ & 2.92 & 2.79 & 2.67 & 2.77 & 0.82 \\
\hline $\begin{array}{l}\text { FCE } \\
(\%)^{*}\end{array}$ & $34.23^{\mathrm{b}}$ & $35.76^{\mathrm{ab}}$ & $37.39^{\mathrm{a}}$ & $36.03^{\mathrm{ab}}$ & 0.76 \\
\hline
\end{tabular}

$n s=$ not significant $(P>0.05)$

$*=$ Significant at $5 \%$ level of significance $(P<0.05)$

$* *=$ Significant at $1 \%$ level of significance $(P<0.01)$

Table 7 shows the dressing percentage with and without giblets, liver and pancreas weights of the colored broiler chicken. The dressing percentage of the colored broiler chicken, with and without giblets, revealed insignificant differences among treatments. This means that the different levels of oregano leaf added to the colored broiler chicken diets did not show any changes significantly in the dressing percentage, with and without giblets.

Table 7. Dressing Percentage with and without Giblets (\%), Liver and Pancreas Weight (grams) of the Colored Broiler Chicken Fed Diet Supplemented with Oregano (Plectranthus amboinicus) Leaf Meal

\begin{tabular}{|c|c|c|c|c|c|}
\hline \multirow[b]{2}{*}{ Parameter } & \multicolumn{4}{|c|}{ Treatment } & \multirow{2}{*}{$\begin{array}{l}\text { C.V. } \\
\%\end{array}$} \\
\hline & $\mathrm{T}_{1}$ & $\mathrm{~T}_{2}$ & $\mathrm{~T}_{3}$ & $\mathrm{~T}_{4}$ & \\
\hline $\begin{array}{l}\text { Dressing } \\
\text { Percentage (With } \\
\text { Giblets) }^{\text {ns }} \\
\text { Dressing }\end{array}$ & 75.61 & 77.11 & 80.42 & 78.24 & 6.88 \\
\hline $\begin{array}{l}\text { Percentage } \\
\text { (Without }^{\text {Giblets) }} \\
\text { (ns }^{\text {Wib }}\end{array}$ & 69.80 & 72.20 & 72.10 & 70.39 & 7.29 \\
\hline $\begin{array}{l}\text { Liver Weight } \\
(\mathrm{g})^{\mathbf{n s}}\end{array}$ & 31.83 & 42.17 & 45.83 & 34.00 & 15.06 \\
\hline $\begin{array}{l}\text { Pancreas Weight } \\
(\mathrm{g})^{\text {ns }}\end{array}$ & 2.67 & 3.17 & 3.83 & 3.50 & 37.97 \\
\hline
\end{tabular}

$n s=$ not significant $(P>0.05)$

Insignificant differences were also obtained in terms of the liver weight with the mean of the different treatments ranging from 31.83 grams to 45.83 grams. Likewise, the pancreas weight revealed insignificant result. The result showed that there was no possible toxicity observed based on the liver and pancreas weights of colored broiler chicken since there was no observed increase on the liver and pancreas based from the control.

The return above feed costs of the colored broiler chicken fed with and without oregano leaf meal is presented in Table 8. Colored broiler chicken fed with 6 grams oregano leaf meal on their ration had the highest return of P88.89, followed by those colored broiler chicken fed with 9 grams oregano leaf meal with Php78.50 return, colored broiler chicken fed without 3\% oregano leaf meal with Php
74.22. The least was those colored broiler chicken fed without oregano leaf meal with a return of Php 50.47. The high income derived from the colored broiler chicken fed diet containing 6 grams of oregano leaf meal could reduce feed cost.

Table 8. Income Over Feed and Chick Cost

\begin{tabular}{lcccc}
\hline \multicolumn{1}{c}{ ITEM } & $\mathrm{T}_{1}$ & $\mathrm{~T}_{2}$ & $\mathrm{~T}_{3}$ & $\mathrm{~T}_{4}$ \\
\hline $\begin{array}{l}\text { Weight gain per } \\
\text { broiler }(\mathrm{g})\end{array}$ & 1.55 & 1.66 & 1.77 & 1.62 \\
$\begin{array}{l}\text { Return per broiler } \\
(150 / \mathrm{kg})\end{array}$ & 264.00 & 276.00 & 288.00 & 271.50 \\
$\begin{array}{l}\text { Amount of } \\
\text { formulated feed }\end{array}$ & & & & \\
consumed $(\mathrm{kg})$ & 2.26 & 2.28 & 2.29 & 2.27 \\
$1^{\text {st }}-4^{\text {th }}$ weeks & 3.06 & 3.14 & 3.14 & 2.91 \\
$5^{\text {th }}-8^{\text {th }}$ weeks & & & & \\
$\begin{array}{l}\text { Price of Feeds per kg } \\
\text { Starter feeds }\left(1^{\text {st }}-4^{\text {th }}\right)\end{array}$ & 28.91 & 28.48 & 26.87 & 27.02 \\
$\begin{array}{l}\text { Finisher feeds }\left(5^{\text {th }}-\right. \\
\left.8^{\text {th }}\right)\end{array}$ & 27.11 & 26.07 & 26.16 & 26.41 \\
$\begin{array}{l}\text { Cost of feeds } \\
\text { consumed }\end{array}$ & & & & \\
Starter feeds $\left(1^{\text {st }}-4^{\text {th }}\right)$ & 83.12 & 81.82 & 82.25 & 76.89 \\
$\begin{array}{l}\text { Finisher feeds }\left(5^{\text {th }}-\right. \\
\left.8^{\text {th }}\right)\end{array}$ & & & & \\
Price of chicks/head & 55.00 & 55.00 & 55.00 & 55.00 \\
Total Expenses & 213.53 & 201.78 & 199.02 & 193.00 \\
\hline $\begin{array}{l}\text { Return Above Feed } \\
\text { Cost }\end{array}$ & 50.47 & 74.22 & 88.89 & 78.50 \\
\hline & & & \\
\hline
\end{tabular}

\section{CONCLUSION AND RECOMMENDATION}

In conclusion, broilers supplemented with $6 \%$ oregano leaf meal obtained the highest gain in weight and body weight. The broilers also with $6 \%$ OLM were the most efficient in converting feeds into weight gain. Hence, the study observe and suggest that the oregano leaf meal (OLM) supplementation on the broilers diet could improve the growth performance and can be safely used as feed ingredients without any deleterious effect. More works is needed of oregano leaf meal particularly at higher levels with emphasis on other criteria such as effects on the intestinal villi development and in terms of meat quality to further clarify the effectiveness of the oregano leaf meal in broiler nutrition as a natural alternative growth promoter.

\section{ACKNOWLEDGMENT}

The authors would like to thank the Department of Animal Sience and Animal Husbandry, College of Agriculture at Isabela State University, Echague, Isabela for the support and allowing the researchers to conduct their research study.

\section{REFERENCES}

[1] Alçiçek, A., M. Bozkurt, and M. Çabuk. 2003. The effect of an essential oil combination derived from selected herbs growing wild in Turkey on broiler performance. S. Afr. J. Anim. Sci. 33:89-94.

[2] Alçiçek, A., M. Bozkurt, and M. Çabuk. 2004. The effect of a mixture of herbal essential oils, an organic acid or a probiotic on broiler performance. S. Afr. J. Anim. Sci. 34:217-222.

[3] Burt, S. 2004. Essential oils: Their Antibacterial Properties and Potential Applications in Foods-A review. Int. J. Food Microbiol. 94:223-253.5.

[4] Demir, E., S. Sarica, M. A. Özcan, and M. Suicmez. 2003. The use of natural feed additives as alternatives for an antibiotic growth promoter in broiler diets. Br. Poult. Sci. 44(Suppl.):S44-S45.

[5] El-Hakim, A. S. A., G. Cherian, El-Hakim, A. S. A., G. Cherian, and M. N. Ali. 2009. Use of organic acid, herbs and their 
combination to improve the utilization of commercial low protein broiler diets. Int. J. Poult. Sci. 8:14-20.

[6] Ertas, O. N., T. Güler, M. Çiftçi1, B. Dalkihç1, and Ü. G. Simsek. 2005. The effect of an essential oil mix derived from oregano, clove and anise on broiler performance. Int. J. Poult. Sci. 4:879-884.

[7] Fallah, R., A. Kiani and A. Azarfar. 2013. A Review of the Role of Five Kinds of Alternatives to In-feed antibiotics in Broiler Production. Journal of Veterinary Medicine and Animal Health. Vol. 5(11), pp. 317-321,

[8] Fukayama, E. H., A. G. Bertechini, A. Geraldo, R. K. Kato, and L. D. S. Murgas. 2005. Oregano Extract as an Additive in the Broiler diet. R. Bras. Zootec. 34:2316-2326

[9] Giannenas, I. A., P. Florou-Paneri, M. Papazahariadou, N. A. Botsoglou, E. Christaki, and A. B. Spais. 2004. Effect of Diet Supplementation with Ground Oregano on Performance of Broiler Chickens Challenged with Eimeria tenella. Arch. Geflugelkd. 68:247-252. 6

[10] Hassan, I. I., A. A. Askar, and G. A. El-Shourbagy. 2004. Influence of some medicinal plants on performance: Physiological and meat quality traits of broiler chicks. Egypt. Poult. Sci. J. 24:247-266.

[11] Halle, I., R. Thomann, U. Bauermann, M. Henning, and P. Köhler. 2004. Effects of a graded supplementation of herbs and essential oils in broiler feed on growth and carcass traits. Landbauforsch. Völkenrode 54:219-229.

[12] Iheukwumere, F.C., E.C. Ndubuisi, E.A. Mazi and M. U. Onyekwere.2008. Performance, Nutrient Utilization and Organ Characteristics of Broilers and Cassava Leaf Meal (Manihotesculenta Crantz). Pak. J. Nutri., 7: 13-16.

[13] Amroz, D., A. Wiliczkiewicz, T. Wertelecki, J. Orda, and J. Skorupińska. 2005. Use of active substances of plant origin in chicken diets based on maize and locally grown cereals. Br. Poult. Sci. 46:485-493.

[14] Kapica, M., M. Kwiecien, I. Puzio, M. Bienko, R. P. Radzki, and M. Pawlowska. 2006. Influence of some herbs on the activity of digestive enzymes in chickens. Med. Weter. 62:1048-1050.

[15] Karimi , F. Yan , C. Coto , J. H. Park, Y. Min, C. Lu , J. A. Gidden , J. O. Lay Jr. , and P. W. Waldroup. 2010. Effects of level and source of oregano leaf in starter diets for broiler chicks, Inc. J. Appl. Poult. Res. 19:137-145.

[16] Kulchaiyawat O, and Honeyman S, professor, department of animal science. (2006). Effects of Oregano Supplemented Diets on Nursery Pig Performance. Iowa State University Animal Industry Report.

[17] Lee, K. W., H. Everts, and A. C. Beynen. 2004. Essential Oils in Broiler Nutrition. Int. J. Poult. Sci. 3:738-752

[18] Reyes, J.L., 2005. Upgrading of Native Chicken by Crossing with Exotic Breeds. CVARRD RDE Journal pp. 1-15.

[19] Sadeghi, G.H and S.A Tabiedian 2005. Effect of Different Enery to Protein Ratio and Tallow Supplementation on Broiler Performance. Int. Journ Poult. Sci. 4(12): 976-981

\section{AUTHOR'S PROFILE}

LILIBETH S. LANGUIDO, is a graduate of Bachelor of Agricultural Technology major in Animal Science at Isabela State University San Mariano Campus in 1999. She took and passed the licensure examination for agriculturist in 2007, Finished her Master's degree at Isabela State Univerisity Echague Campus. At present she is currently employed as faculty of the Agriculture department of

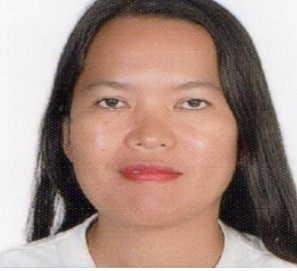
Isabela State University San Mariano Campus, As an animal science faculty, she is the project in-charge of the livestock section of the campus managing the swine, poultry and sheep production. She is a member of the Philippine Society of Animal Science (PSAS) and her field of specialization is in swine and sheep production.

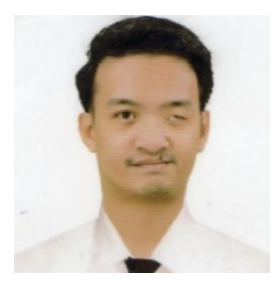

MARK JOKER L. MARCOS, is a graduate of Animal Science at Isabela State University both his Bachelor's and Master's degree. He is a Licensed Agriculturist. Presently, he is employed as Faculty of the Department of Animal Science \& Animal Husbandry, College of Agriculture, Isabela State University, Echague, Isabela. As faculty-researcher he is handling and involved in various research work in the University particularly in the field of Small Ruminant and Poultry. Mr. Marcos also is an active member of Philippine Association for Agriculturist (PAA), Philippine Society of Animal Science (PSAS), Philippine Association of Extension Program Implementors, Inc. (PAEPI) and Philippine Association for Laboratory Animals (PALAS). 